\title{
Effect of 22(S), 23(S)-Homobrassinolide on Adventitious Root Formation in Grape Rootstocks
}

\author{
U. Kaplan, Z. Gökbayrak* \\ Department of Horticulture, Faculty of Agriculture, Çanakkale Onsekiz Mart University, 17020 Çanakkale, Turkey
}

Submitted for publication: April 2012

Accepted for publication: July 2012

Key words: Grape, rootstock, brassinosteroid, rooting

\begin{abstract}
In recent times, brassinosteroids have been identified as a group of hormones that regulate plant growth and development. They affect plant development from seed germination to senescence. The aim of this research was to study the effects of brassinosteroids on the rooting of three American grapevine rootstocks (1103 Paulsen, 110 Richter and 99 Richter) used frequently to produce grafted grapevines. Rootstock cuttings were dipped for 10 minutes into five different concentrations of 22(S), 23(S)-homobrassinolide and planted into a peat-perlite mixture. Data such as fresh and dry root weight, root number and development level were collected and assessed. Some shoot growth features were also determined. The results showed that the grapevine rootstocks with the most significant response in improved root and shoot growth were 1103 Paulsen, followed by 110 Richter. Root development level was influenced by both the rootstock and the concentrations of the substance. The lowest concentration, $0.05 \mathrm{ppm}$, induced more root numbers in 1103 Paulsen, while 0.15 ppm resulted in the highest number of roots in 99 Richter. A statistical analysis of the data revealed a significant difference between root development and shoot growth.
\end{abstract}

\section{INTRODUCTION}

Plant hormones have been classified into five groups: auxins, gibberellins, cytokinins, abscisic acid and ethylene. However, another group of chemical compounds called brassinosteroids have emerged as the sixth group of plant hormones. These compounds were first isolated from rape (Brassica napus L) pollens in 1979 (Rao et al., 2002), and subsequently in other plants (Sasse, 1997). Brassinosteroids collectively refer to naturally occurring $5 \alpha$-cholestane steroids that elicit growth stimulation in nano- or micromolar concentrations (Clouse \& Sasse, 1998; Choe, 2004).

Research conducted to study the effects ofbrassinosteroids on different developmental stages of various plant species have focused primarily on determining their impacts on seed germination and alleviating stress effects on development (Vardhini \& Rao, 1997; Leubner-Metzger, 2001; Anuradha $\&$ Rao, 2003). However, the influence of brassinosteroids on the growth and development of perennial species has not been researched extensively. This study was carried out to test the effect of brassinosteroids on the rooting of woody species, mainly three American grapevine rootstock hybrids.

\section{MATERIALS AND METHODS}

One-year-old dormant cuttings of three American hybrid rootstocks (1103 Paulsen, 110 Richter and 99 Richter, the hybrids of $V$. berlandieri $\mathrm{x} V$. rupestris) were obtained from the Viticultural Research Institute of Tekirdağ in Turkey. Cuttings were collected from the middle section of the canes intended for grafting (6 to $8 \mathrm{~mm}$ in diameter). Bundles of cuttings were kept in a black polyethylene bag in a cold storage room at 1 to $2{ }^{\circ} \mathrm{C}$ and $80 \%$ relative humidity until the experiment was set.

Cuttings were prepared as two-bud sections with the lower bud removed. Five different concentrations (control, 0.05, $0.10,0.15$ and $0.25 \mathrm{ppm}$ ) of 22(S), 23(S)-homobrassinolide (Sigma H-1267) was prepared and the cuttings were dipped into the solutions for $10 \mathrm{~min}$. The control group was dipped in distilled water. Plastic pots $(13 \times 20 \times 7 \mathrm{~cm})$, filled with perlite and peat moss $(1: 2 \mathrm{v} / \mathrm{v})$, were used for growing the cuttings. The pots were then placed in a climatic chamber (24 to $26^{\circ} \mathrm{C}$ and $80 \%$ relative humidity) under conditions of $16 \mathrm{hrs}$ light and $8 \mathrm{hrs}$ dark. The experiment was ended when sprouting plants no longer showed signs of growth (approximately after 10 weeks).

After finalising the experiments, the following measurements were taken according to the method described by Dardeniz et al. (2008): 1) root development level on a scale of 0 to 4 ( $0=$ no root formation, $1=$ one-sided weak root formation, 2 = two-sided root formation, $3=$ three-sided root formation, and 4 = four-sided root formation); 2) root fresh and dry weights $(\mathrm{g}) ; 3)$ number of roots at least in $1 \mathrm{~mm}$ length; 4) primary shoot length $(\mathrm{cm}) ; 5)$ node number on the

*Corresponding author: e-mail: zgokbayrak@comu.edu.tr [Tel.: +902862180018/1309; Fax: +902862180545]

Acknowledgements: This research was funded by the Scientific Research Projects Commission of the Çanakkale Onsekiz Mart University (project number

2010/51) and carried out by the first author as a Master's thesis under the supervision of the second author, who was also the project leader. We would like to express our gratitude to the graduates, Yasemin Çakmak and Şule Gökbulak, for their invaluable contributions in conducting the experiment 
main shoot; 6) sprouted cuttings (\%); 7) rooted cuttings (\%); and 8 ) healthy plant $(\%)$ with live shoot and roots together.

The study was conducted in a randomised parcels trial design, with four replicates and 15 cuttings per replicate. The data obtained was evaluated with Minitab (Release 13.1, Minitab Inc.) for two-way ANOVA for the treatments and rootstocks, and the differences were tested with Duncan's multiple range test. Correlation and regression analyses were also performed on the characteristics using the same statistical program.

\section{RESULTS}

Clear effects of the 22(S), 23(S)-homobrassinolide were seen in the root development level of the cuttings (Table 1). The most significant development was observed in 1103 Paulsen cuttings treated with $0.05 \mathrm{ppm}$, while 99 Richter cuttings treated with $0.15 \mathrm{ppm}$ had the highest root development. 110 Richter cuttings did not show any statistically important differences in relation to the concentrations applied.

22(S), 23(S)-homobrassinolide did not have a specific influence on the root number at the base of the cuttings. However, the rootstocks manifested their inherent characteristics and showed significant variation in the number of roots, in the decreasing order of 110 Richter (4.89), 1103 Paulsen (3.84), and 99 Richter (2.80). Fresh root weight similarly responded to the change in the root number, being $0.655 \mathrm{~g}, 0.515 \mathrm{~g}$ and $0.301 \mathrm{~g}$ in the 110 Richter, 1103 Paulsen and 99 Richter respectively. However, the dry root weights of the 110 Richter $(0.056 \mathrm{~g})$ and 1103 Paulsen $(0.050 \mathrm{~g})$ were similar, and statistically higher than that of 99 Richter $(0.031 \mathrm{~g})$.

Shoot growth of the rootstock cuttings was not affected by the application. 1103 Paulsen showed a superior development in shoot length $(11.60 \mathrm{~cm})$ and node number per primary shoot $(4.51)$, compared to 110 Richter $(7.16 \mathrm{~cm}$ and 2.70) and 99 Richter (6.66 cm and 3.42). The percentage of cuttings that rooted and turned into healthy plants was highest in 1103 Paulsen (69.17\%), followed by 110 Richter (53.50\%) and 99 Richter (45\%).

Correlation analyses showed some statistically important $(\mathrm{p}=0.000)$ positive correlations between the root growth and shoot growth aspects (Table 2), depending on the rootstock cultivar. In general, these correlations were between root development level, root number, shoot length and node number. Similar significant and positive correlations were observed between rooted plants and shoot length and node number. The correlations were higher in the 99R and 1103P cuttings compared to those in the 110R cuttings.

Regression analyses carried out on the parameters indicating significant correlations (Table 3) showed that root number on a cutting was more sensitive to the node number than the shoot length. However, this changed with node number than the shoot length. Root development level was influenced by both changes in the shoot length and node number. It was more sensitive to the node number, with a slope of more than double compared to the shoot length. On the other hand, their cumulative effects resulted in a similar slope in the lines by the variables alone.

\section{DISCUSSION}

Information on the effects of brassinosteroids on the root growth of woody plants is scarce. This research was an attempt to report on the effects of 22(S), 23(S)homobrassinolide on the root development and growth in grapevine rootstock cuttings. 1103 Paulsen, 110 Richter and 99 Richter have different inherent characteristics as far as the rooting ability of their cuttings is concerned. The former is easiest to root among the three, while $110 \mathrm{R}$ roots harder compared to $99 \mathrm{R}$. The response of the rootstocks to the chemical applied were not clear enough to safely conclude that 22(S), 23(S)-homobrassinolide either promotes or inhibits the root growth and development of the cuttings. It has been reported in the literature that the growth-promoting activity of brassinosteroids generally occurs if the plants are treated in the appropriate phase of development, and within a certain concentration range (Khripach et al., 1999). In the present experiment, the minimum concentration seemed to improve the general development of the roots, while the higher concentrations did not support better rooting. From the inclination of the plants responding to lower concentrations, it could be deduced that even lower concentrations would have given better results. Rönsch et al. (1993) also found that the lowest concentration of 22(S), 23(S)-homobrassinolide they used (3 ppm) was near optimum in terms of rooting percentage in Norway spruce cuttings.

The type of chemical has also been reported to have an influence on rooting. Swamy and Rao (2006) reported a more marginal effect of 28-homobrassinolide than 24-epibrassinolide when applied to geranium stem cuttings. Guan and Roddick (1988) showed inhibition of adventitious root formation in mung bean hypocotyls by 24-epibrassinolide. The chemical used in this study might be a reason for the rootstock cuttings showing inconclusive reactions.

The close relationship between root number and development level with node number shows that the more node there are, and hence new expanding leaves borne on a shoot, the more auxin-producing sites are on the shoot. An interaction between brassinosteroid and auxin at the rooting site might have resulted in the promotion of root formation around the base of the cuttings. Auxin response has been found to be connected to brassinosteroid, acting in concert with auxin to induce root growth in maize (Kim et al., 2000). Brassinosteroid and auxin are significant growth regulators that have effects on cell division and expansion, and on root growth (Bao et al., 2004). Hardtke et al. (2007) showed collaboration between the two compounds to modulate cell expansion and proliferation with overlapping activities. Similarly, Mandava (1988) reported the promotion of cell elongation when brassinosteroid was supplied with auxin.

\section{CONCLUSIONS}

Variations in responses to the application of brassinosteroid seem to indicate that the correct concentrations might differ with rootstock cultivar. It would be worthwhile to study this further in order to find the right concentrations, timing and type of the compounds that result in better root development, especially in harder-to-root cultivars. 
TABLE 1

Effect of 22(S), 23(S)-homobrassinolide on the root and shoot development of grapevine rootstocks (Vitis sp.).

\begin{tabular}{ccccccccccc}
\hline & $\begin{array}{c}\text { 22(S), 23(S)- } \\
\text { homobrassinolide } \\
(\mathrm{ppm})\end{array}$ & $\begin{array}{c}\text { Root } \\
\text { number }\end{array}$ & $\begin{array}{c}\text { Root } \\
\text { development } \\
(0-4 \text { scale })\end{array}$ & $\begin{array}{c}\text { Fresh root } \\
\text { weight } \\
(\mathrm{g})\end{array}$ & $\begin{array}{c}\text { Dry root } \\
\text { weight } \\
(\mathrm{g})\end{array}$ & $\begin{array}{c}\text { Shoot } \\
\text { length } \\
(\mathrm{cm})\end{array}$ & $\begin{array}{c}\text { Node } \\
\text { number main } \\
\text { shoot }\end{array}$ & $\begin{array}{c}\text { Cuttings Cuttings } \\
\text { rooted } \\
(\%)\end{array}$ & $\begin{array}{c}\text { Healthy } \\
\text { sprouted } \\
(\%)\end{array}$ & $\begin{array}{c}\text { plant } \\
(\%)\end{array}$ \\
\hline 1103 Paulsen & 0.05 & 4.23 & $2.48 \mathrm{a}$ & 0.689 & 0.050 & 12.67 & 4.55 & 85.33 & 93.34 & 75.83 \\
& 0.10 & 3.64 & $1.59 \mathrm{~b}$ & 0.483 & 0.048 & 12.11 & 4.72 & 76.67 & 90.83 & 73.33 \\
& 0.15 & 3.63 & $1.88 \mathrm{~b}$ & 0.531 & 0.054 & 11.65 & 4.77 & 80.00 & 97.50 & 66.67 \\
& 0.25 & 3.99 & $2.02 \mathrm{ab}$ & 0.513 & 0.048 & 12.81 & 4.78 & 82.50 & 93.33 & 71.67 \\
& Control & 3.70 & $1.66 \mathrm{~b}$ & 0.360 & 0.049 & 8.79 & 3.74 & 70.83 & 90.00 & 58.34 \\
& Mean & $3.84 \mathrm{~B}$ & 1.92 & $0.515 \mathrm{~B}$ & $0.050 \mathrm{~A}$ & $11.60 \mathrm{~A}$ & $4.51 \mathrm{~A}$ & $79.17 \mathrm{~A}$ & $93.00 \mathrm{~A}$ & $69.17 \mathrm{~A}$ \\
\hline 110 Richter & 0.05 & 5.01 & $1.79 \mathrm{a}$ & 0.739 & 0.055 & 7.79 & 2.78 & 57.50 & 55.83 & 50.83 \\
& 0.10 & 5.56 & $1.88 \mathrm{a}$ & 0.505 & 0.072 & 7.73 & 2.77 & 65.00 & 64.17 & 56.67 \\
& 0.15 & 3.76 & $1.66 \mathrm{a}$ & 0.605 & 0.042 & 5.90 & 2.35 & 61.67 & 59.17 & 55.83 \\
& 0.25 & 5.06 & $1.71 \mathrm{a}$ & 0.719 & 0.052 & 6.33 & 2.51 & 55.83 & 59.17 & 52.50 \\
& Control & 5.08 & $1.76 \mathrm{a}$ & 0.707 & 0.058 & 8.06 & 3.11 & 56.67 & 65.83 & 51.67 \\
& Mean & $4.89 \mathrm{~A}$ & 1.76 & $0.655 \mathrm{~A}$ & $0.056 \mathrm{~A}$ & $7.16 \mathrm{~B}$ & $2.70 \mathrm{C}$ & $59.33 \mathrm{~B}$ & $60.83 \mathrm{~B}$ & $53.50 \mathrm{~B}$ \\
\hline
\end{tabular}

TABLE 2

Correlation analysis results of the grapevine rootstocks treated with 22(S), 23(S)-homobrassinolide.

\begin{tabular}{|c|c|c|c|c|}
\hline Rootstocks & & Parameters & Correlation (r) & $P$ value \\
\hline \multirow[t]{6}{*}{1103 Paulsen } & Shoot length $(\mathrm{cm})$ & Root number (n) & 0.729 & 0.000 \\
\hline & & Root development (0-4 scale) & 0.707 & 0.000 \\
\hline & & Rooted plant (\%) & 0.833 & 0.000 \\
\hline & Node number & Root number (n) & 0.645 & 0.000 \\
\hline & & Root development (0-4 scale) & 0.601 & 0.000 \\
\hline & & Rooted plant (\%) & 0.817 & 0.000 \\
\hline \multirow[t]{2}{*}{110 Richter } & Shoot length & Root development (0-4 scale) & 0.436 & 0.040 \\
\hline & Node number & & 0.528 & 0.017 \\
\hline \multirow[t]{6}{*}{99 Richter } & Shoot length $(\mathrm{cm})$ & Root number (n) & 0.710 & 0.000 \\
\hline & & Root development (0-4 scale) & 0.768 & 0.000 \\
\hline & & Rooted plant (\%) & 0.444 & 0.050 \\
\hline & Node number & Root number (n) & 0.709 & 0.000 \\
\hline & & Root development (0-4 scale) & 0.790 & 0.000 \\
\hline & & Rooted plant (\%) & 0.547 & 0.013 \\
\hline
\end{tabular}

TABLE 3

One-variable regression models of the individual rootstocks to describe the relationships between root number/root development level or rooted plant percentage and shoot length and node number of the rootstocks, independent of the concentrations of the substance. $\mathrm{x}=$ shoot length, $\mathrm{z}=$ node number.

\begin{tabular}{|c|c|c|c|c|}
\hline Rootstock & Parameter & Regression model & $\mathbf{R}^{2}$ & P value \\
\hline \multirow{7}{*}{1103 Paulsen } & \multirow{2}{*}{ Root number (n) } & $y=0.192 x+1.61$ & 53.1 & 0.000 \\
\hline & & $y=0.540 z+1.40$ & 41.6 & 0.002 \\
\hline & \multirow{3}{*}{ Root development (0-4 scale) } & \multirow{3}{*}{$\begin{array}{l}y=0.124 x+0.483 \\
y=0.335 z+0.412\end{array}$} & 50.0 & 0.000 \\
\hline & & & 36.1 & 0.005 \\
\hline & & & 41.0 & 0.000 \\
\hline & \multirow{2}{*}{ Rooted plant (\%) } & $Y=3.21 x+41.9$ & 69.5 & 0.000 \\
\hline & & $Y=9.99 z+34.1$ & 66.7 & 0.000 \\
\hline \multirow{2}{*}{110 Richter } & \multirow{2}{*}{ Root development (0-4 scale) } & $y=0.0143 x+1.46$ & 21.4 & 0.040 \\
\hline & & $y=0.164 z+1.32$ & 27.8 & 0.017 \\
\hline
\end{tabular}


TABLE 3 (CONTINUED)

\begin{tabular}{llcll}
\hline Rootstocks & Parameters & Correlation (r) & P value \\
\hline \multirow{2}{*}{ 99 Richter } & \multirow{2}{*}{ Root number (n) } & $\mathrm{y}=0.339 \mathrm{x}+0.539$ & 50.4 & 0.000 \\
& & $\mathrm{y}=0.786 \mathrm{z}+0.108$ & 50.3 & 0.000 \\
& \multirow{2}{*}{ Root development (0-4 scale) } & $\mathrm{y}=0.160 \mathrm{x}+0.651$ & 58.9 & 0.000 \\
& & $\mathrm{y}=0.381 \mathrm{z}+0.410$ & 62.5 & 0.000 \\
& \multirow{2}{*}{ Rooted plant (\%) } & $\mathrm{Y}=1.32 \mathrm{x}+43.7$ & 19.7 & 0.050 \\
& & $\mathrm{Y}=3.77 \mathrm{z}+39.6$ & 30.0 & 0.013 \\
\hline
\end{tabular}

\section{LITERATURE CITED}

Anuradha, S. \& Rao, S.S.R., 2003. Application of brassinosteroids to rice seeds (Oryza sativa L.) reduced the impact of salt stress on growth, prevented photosynthetic pigments loss and increased nitrate reductase activity. Plant Growth Regul. 40, 29-32.

Bao, F., Shen, J., Brady, S.R., Muday, G.K., Asami, T. \& Yang, Z., 2004 Brassinosteroids interact with auxin to promote lateral root development in Arabidopsis. Plant Physiol. 134, 1624-1631.

Choe, S., 2004. Brassinosteroid biosynthesis and metabolism. In: Davies, P.J. (ed). Plant hormones: biosynthesis, signal transduction, action. Kluwer Academic Publishers, Dordrecht, The Netherlands. Pp 156-178.

Clouse, S.D. \& Sasse, J.M., 1998. Brassinosteroids: essential regulators of plant growth and development. Annu. Rev. Plant Physiol. Plant Mol. Biol $49,427-451$.

Dardeniz, A., Gökbayrak, Z., Müftüoğlu, N.M., Türkmen, C. \& Beșer, K., 2008. Cane quality determination of $5 \mathrm{BB}$ and $140 \mathrm{Ru}$ grape rootstocks. Eur. J. Hortic. Sci. 73(6), 254-258

Guan, M. \& Roddick, J.G., 1988. Epibrassinolide-inhibition of development of excised, adventitious and intact roots of tomato (Lycopersicon esculentum): comparison with the effects of steroidal estrogens. Physiologia Plantarum 74, 720-726.

Hardtke, C.S., Dorsey, E., Osmont, K.S. \& Sibout, R., 2007. Phytohormone collaboration: zooming in on auxin-brassinosteroid interactions. Trends Cell Biol. 17(10), 485-492.
Khripach, V.A., Zhabinskii, V.N. \& De Groot, A.E., 1999. Brassinosteroids: a new class of plant hormones. Academic Press, Inc., San Diego. ISBN 0-12-406360-8.

Kim, S.K., Chang, S.C., Lee, E.J., Chung, W.S., Kim, Y.S., Hwang, S. \& Lee, J.S., 2000. Involvement of brassinosteroids in the gravitropic response of primary root of maize. Plant Physiol. 123, 997-1004.

Leubner-Metzger, G., 2001. Brassinosteroids and gibberellins promote tobacco seed germination by distinct pathways. Planta 213, 758-763.

Mandava, N.B., 1988. Plant growth-promoting brassinosteroids. Annu. Rev. Plant Physiol. Plant Mol. Biol. 39, 23-52.

Rao, R.S.S., Vardhini, B.V., Sujatha, E. \& Anuradha, S., 2002 Brassinosteroids - a new class of phytohormones. Curr. Sci. 82(10), 12391245

Rönsch, H., Adam, G., Matschke, J. \& Schachler, G., 1993. Influence of (22S,23S)-homobrassinolide on rooting capacity and survival of adult Norway spruce cuttings. Tree Physiol. 12, 71.

Sasse, J.M., 1997. Recent progress in brassinosteroid research. Physiologia Plantarum 100, 697-701.

Swamy, K.N. \& Rao, S.S.R., 2006. Influence of brassinosteroids on rooting and growth of geranium (Pelargonium sp.) stem cuttings. Asian J. Plant Sci. 5(4), 619-622.

Vardhini, B.V. \& Rao, S.S.R., 1997. Effect of brassinosteroids on salinity induced growth inhibition of ground nut seedlings. Indian J. Plant Physiol. 2(2), 156-157. 